International Journal of Biology, Pharmacy and Allied Sciences (IJBPAS) 'A Bridge Betueen Caboratory and QRendo'

Www.ijbpas.com

\title{
PROBLEMS OF ROSE CULTIVATORS IN SOLAPUR DISTRICT,
} MAHARASHTRA, INDIA

\section{BHANJE BM ${ }^{1}$ AND RATHOD RH ${ }^{2 *}$}

1: Head Department of Geography, Santosh Bhimrao Patil Arts, Commerce \& Science College, Mandrup, Solapur, Maharashtra, India.

2: Department of Geography, Nowrosjee Wadia College, Pune, Maharashtra, India

"Corresponding Author: Ranjana H. Rathod; E Mail: ranjana.rathod006@gmail.com

Received $10^{\text {th }}$ June 2021; Revised $11^{\text {th }}$ July 2021; Accepted $20^{\text {th }}$ Aug. 2021; Available online $15^{\text {th }}$ Jan. $_{2022}$

https://doi.org/10.31032/IJBPAS/2022/11.1.1088

\begin{abstract}
Roses and gardens have long been admired in India for their aesthetic, religious, economic, and social significance. For many years, farmers have grown them as a commercial crop. The goal of this study is to learn about rose growers' characteristics in order to assess the relationship between selected personal, social, economic, and psychological characteristics of rose growers and their adoption of rose production technologies, particularly rose flowers, as well as the challenges they face in rose production, management, and marketing. To boost adoption and profit from this profitable industry, it is critical to understand the constraints and ways for overcoming them.
\end{abstract}

\section{Keywords: Rose cultivators, Solapur district, Production, technology, problem}

\section{INTRODUCTION}

Roses are always profitable flower crop in the horticulture sector. Roses can be used in a number of different ways, depending on the species and types. Rose oil, rose water, gulkhand, number of sweets and cosmetic products are all made from them. The model project focuses on the manufacture of cut roses, which play an essential role in bouquets, floral arrangements, worship, social gatherings, and gift presentation. Cut roses are the most popular in terms of volume of commerce on the worldwide market. Furthermore, with advancements in cut rose 
production and marketing, as well as recent economic liberalisation, there has been a spike in interest in producing cut roses in plastic green houses in India. Floriculture means the cultivation of flower and ornamental plants within the garden and arable land (Biswas, 2013) for commercial purposes (Mishra and Mishra, 2016). Rose and Jasmine flowers are utilised in a variety of commercial and edible uses.

Every year, the Solapur district of Maharashtra grows more roses than any other part of India. Many districts in Maharashtra farmers are grown in their farms various type of loose flowers. Because the significance of many religious places and temples in Maharashtra, as well as Solapaur's major Sidhheshwar festival (Yatra) conducted every year in monthof January. The roses cultivated in Solapur are not planned for competitions or shows. If these are to be categorised, they are desi or local varieties, not varieties of any significance. All of these roses are red colour.

Every year, between mid-January and midMarch, rose blooms have a lean time when they are few and far between.Fresh roses are not delivered to the far locations because they are extremely delicate to pack, handle, and transport, and their durability is significantly inferior to that of other flowers used for decorative purposes such as and. As a result, the destination of fresh roses exported both within and outside the country must be within 24 hours. The dried flowers or petals are the most common form of rose export from Solapur to other districts and beyond. and are key importers of dried rose petals from Solapur. When roses are exported, they are packaged in baskets or sack cloth.

Gulkand is a by-product of roses that is used to calm the throat and as a component in the preparation of sweet betel or meethapaan. The use of rose water to wash the eyes soothes the burning feeling and enhances vision. It also works as a deodorant and a moderate air freshener.

\section{STUDY AREA}

Solapur District is a district in Maharashtra state of India. The city of Solapur is the district headquarters. It is located on the south east edge of the state and lies entirely in the Bhima and Seena basins. The entire district is drained by the Bhima River.[According to the 2011 census, the total population of Solapur district is $43,15,527$ and the geographical area is about 14,895 sq. $\mathrm{km}$ divided into 11 tahsils (Barakade and Sule, 2011). It ranks fourth in terms of area (4.88 percent) and seventh in terms of population among Maharashtra's 35 districts (4.51 percent). The district's average annual rainfall is $584.3 \mathrm{~mm}$, due to the study area is rain shadow. 


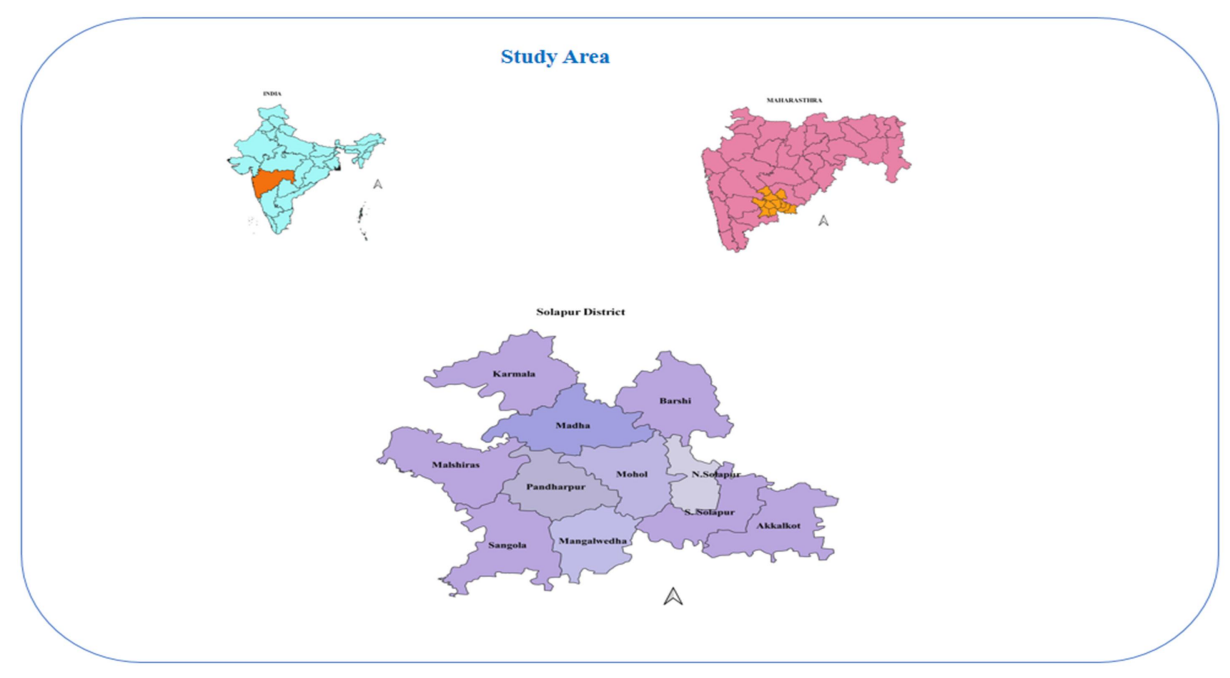

Figure 1: Location map of the study area

\section{DATA BASE AND METHODOLOGY}

The study location and sample were chosen based on the amount of land dedicated to rose cultivation. The district of Solapur was chosen for investigation in the rose cultivation area. Due to the favourable environment and flower market in Solapur, this district was discovered to be the top district in the state for rose cultivation and production.

A pre-tested interview schedule was created to capture the primary data, which was then used in the field survey to collect information at the farm level. The primary data was collected using a direct personal interview method. Secondary data is gathered from horticultural department publications such as books, journals, reports, and records.

\section{RESULTS}

Only a few flower types are produced in
Solapur district.

Flowers are primarily used for garlands and function decorating.

For flower growing, the vast majority of farmers have not taken loans.

Farmers do not have access to necessary transportation.

The storage facilities are insufficient, and the growers do not use the available facilities, resulting in fresh flower waste.

Farmers encounter a number of challenges, including packing and planting.

Farmers face plenty of market-related issues.

\section{DISCUSSION}

The area under floriculture in Solapur is rapidly expanding. There are numerous elements that favour its growth. Farmers are being enticed to switch from low-income crops to high-value flower crops by favourable 
climatic circumstances, increased demand for

flowers, rising per capita income, and highly remunerative prices. In South Solapur district Vadji and Pinajrwadi villages are high rose producing areas in the solapur district

These weaknesses are evident in the data collected on the ground or in peoples impressions of the various infrastructural facilities. These are impeding the development of floriculture and affecting the prospects of Village growers.

Producers concerns or limits have been roughly categorised as follows:

(a) Problems with storage

(b) Transport-related issues

(c) Issues with the materials

(d) Market-related issues, as well as

(e) Other issues.

\section{a) Storage Facilities Issues}

Maintaining the freshness of the flowers necessitates the use of storage facilities. The flowers studied, on the other hand, are classic types that do not require this. The reason for this is that farmers only grow a little amount of them and sell them rapidly. However, a tiny percentage of conventional flower growers stated that they did not have enough space to store even their little amount of produce. Flowers require cold storage facilities to retain their freshness, quality, texture, and longevity. None of the flower producers, on the other hand, had these facilities, not had the government provided them. Even back then, the bulk of them thought they didn't need this facility because they only grew little amounts and disposed of it as quickly as possible. They also believed that cooperative facilities could assist them in keeping their flowers in cold storage to avoid price volatility.

\section{b) Transport-related issues}

Quality of roads are the major problems faced by flower farmers. In the Solapur district in the villages roads are not metalled. Flowers are a perishable product, thus they sell out quickly in the market. However, because of the weak road network, farmers are having difficulties. Efficient, more reliable, and direct road and rail network to various destinations are required for quick product disposal and better realisation. These facilities are insufficient in Solapur.

\section{c) Material Issues in Packing and Planting}

In the villages studied, the sample farmers impressions on packaging material availability suggested that the majority of the farmers had no problems. However, they claimed that there was a shortage of better packing materials and that the cost of supplies was too expensive. The bulk of the farmers were wrapping their produce in polythene bags or gunny bags for marketing, which they already had, according to observations in the field. In terms of 
planting materials, the majority of farmers voiced dissatisfaction with the lack of quality seeds and better kinds of planting materials.

\section{d) Market Related Problem}

In terms of market restrictions, the sample growers stated a single or a mixture of market constraints. More commission was the most prevalent restraint, followed by the difficulty of middlemen and the deduction of more costs.It was discovered that there was no market information on demand and prices in the communities.

\section{e) Limitations of Production}

A considerable proportion of sampled farmers identified certain critical restraints that are affecting production in addition to the problems. The respondents mentioned groundwater depletion, inadequate irrigation facilities, frequent power outages, and unannounced electricity load shedding as examples.

\section{f) Diseases Issues}

Farmers are becoming increasingly concerned about the spread of pests and diseases among floricultural crops. They have limited understanding of which pesticides are most effective in combating these diseases. They stated that pesticide pricing were expensive, but the quality was poor.

\section{g) Developing Market Access}

Farmers in South Solapur are primarily involved in rose cultivation. According to the survey, rose farmers) do not have enough time to travel to market and sell their product because they are primarily focused on growing. There is no market established for the selling of rose products in South Solapur, therefore they must rely on intermediaries to get their production to Solapur market, which is roughly 30 kilometres distance.

\section{h) Challenges in Recent Floriculture}

In the last four to six years, exports of modern floricultural goods have increased. However, the industry is struggling, and many units have grown ill. Most of the units have lost their perfumes in recent years, and a substantial number of them have been shut down.

\section{i) Other Limitations}

Lack of refrigeration-equipped transport vans to transport flowers to long-distance markets, lack of information about the global market and non-availability of planting materials of varieties suitable for export, procedural delays and insufficient promotional campaigns, have all been blamed for the sectors poor performance. Farmers were also unable to obtain information on market trends, including potential for new varieties, value-added packaging, and advances in other regions of the world.

Overall, the producers face major challenges such as a lack of infrastructure, a lack of 
technology transfer, a lack of inputs such as high-quality seeds and planting materials, a lack of cooperative marketing, high transportation costs, import duties, and irregular power supply in modern floriculture. If the industry is to survive, these issues must be addressed first. Apart from that, new processing units must be encouraged to avoid post-harvest losses and to combat market gluts; otherwise, farmers will continue to encounter issues.

\section{CONCLUSION}

Floriculture also provides a diverse range of options. In the Solapur district, it has developed into a lucrative business arrangement. It has a substantial foreign currency market. It has a lot of potential for employment generation and can help rural economies.Price, plantation, fertiliser, and employment are the factors we've used. According to the report, the industry requires government assistance, such as a government market in Solapur, a marketing committee, and support pricing in order to achieve a distinctive location in the Solapur district. Rose products, such as garlands, rose water, gulkand, and perfumes, are also produced and are quite popular in the Solapur district.

\section{REFERENCE}

[1] Barakade, A. J., and Sule, B. M., (2011. Rainfall variability in Solapur district of
Maharashtra: A geographical study.

Review of Research, Vol. 1 (2), pp. 1-4.

[2] Biswas, N. K., 2013. Floriculture concentration zone of Nadia district, West Bengal. International Journal of Humanities and Social Science Invention, Vol. 2 (1), pp. 14-17

[3] Mishra, N. K., and Mishra, D. P., 2016. A study on entrepreneurial challenges of floriculture in Odisha. International Journal of Computer Engineering in Research trends, Vol. 3 (8), pp. 419424.

[4] C.M. Thakar, S.S. Parkhe, A. Jain et al., 3d Printing: Basic principles and applications, Materials Today: Proceedings, https://doi.org/10.1016/j.matpr.2021.06.27 $\underline{2}$

[5] Khan, R. M. I., Kumar, T., Supriyatno, T., \& Nukapangu, V. (2021). The Phenomenon of Arabic-English Translation of Foreign Language Classes During The Pandemic. Ijaz. Arabi Journal of Arabic Learning, 4(3). https://doi.org/10.18860/ijazarabi.v4i3.135 $\underline{97}$

[6] Sajja, G., Mustafa, M., Phasinam, K., Kaliyaperumal, K., Ventayen, R., \& Kassanuk, T. (2021). Towards Application of Machine Learning in Classification and Prediction of Heart Disease. 2021 Second 
International Conference On Electronics And Sustainable Communication Systems

(ICESC).https://doi.org/10.1109/icesc5142

$\underline{2.2021 .9532940}$

[7] Veluri, R., Patra, I., Naved, M., Prasad, V., Arcinas, M., Beram, S., \&amp; Raghuvanshi, A. (2021). Learning analytics using deep learning techniques for efficiently managing educational institutes. Materials Today: Proceedings. https://doi.org/10.1016/j.matpr.2021.11.41 $\underline{6}$ 